\title{
Persepsi Perawat tentang Spiritual Care di Ruang Intensive Care Unit
}

\author{
${ }^{1}$ Maryana*, ${ }^{2}$ Erwan \\ 1,2Program Studi Ilmu Keperawatan, STIKES Citra Delima Bangka Belitung \\ *Email Korespondensi: maryana385@yahoo.com
}

\section{Kata kunci : \\ Persepsi, \\ spiritual care, \\ perawat, \\ ICU \\ Keywords : \\ Perception, \\ Spiritual Care, \\ Nurses, \\ ICU}

Info Artikel:

\section{Tanggal dikirim:}

02 Oktober 2019

\section{Tanggal direvisi:}

10 Oktober 2019

Tanggal diterima :

28 November 2019

DOI Artikel:

10.33862/citradelima.

v3i2.83

Halaman: 127 - 140

\begin{abstract}
Abstrak
Spiritual care merupakan hal yang penting bagi pasien. Satu - satunya sumber penyembuhan (healing) bagi pasien terminal adalah spiritualitas mereka. Namun dalam pelayanan keperawatan masih terfokus pada aspek fisik. Tujuan penelitian ini adalah untuk mengeksplorasi persepsi perawat tentang spiritual care di ruang Intensive Care Unit (ICU) Rumah Sakit Medika Stannia Sungailiat.Jenis penelitian kualitatif dengan pendekatan fenomonologi. Informan 10 orang dengan teknik non purposive sampling. Tehnik pengumpulan data, wawancara dan observasi. Terdapat 5 tema persepsi perawat tentang spiritual care, yaitu pemahaman perawat tentang spiritual care, cara perawat mengidentifikasi kebutuhan spiritual pasien, pelaksanaan spiritual care, berbagai hambatan dalam pelaksanaan spiritual care, dan harapan terhadap spiritual care : advokasi dalam pembuatan kebijakan di rumah sakit tentang kewajiban perawat melaksanakan spiritual care, upaya bimbingan dalam peningkatan pengetahuan, serta evaluasi berkelanjutan dalam melaksanakan spiritual care di ruangan.
\end{abstract}

\section{Perception of Nurses on Spiritual Care in Intensive Care}

\section{Abstract}

Spiritual care is important for patients. The only healing source for terminal patients is their spirituality. But in nursing service is still focused on the physical aspect. The purpose of this study was to explore the nurse's perception of spiritual care in the Intensive Care Unit (ICU) Hospital of Medika Stannia Sungailiat. Type of qualitative research with phenomonology approach. Informant 10 people with non purposive sampling technique. Data collection techniques, interviews and observation. 5 theme of nurse perception about spiritual care, that is understanding of nurse about spiritual care, nurse way of identifying patient's spiritual needs, spiritual care implementation, various obstacles in the implementation of spiritual care, and hope toward spiritual care. advocate in making policy in the hospital about the obligation of nurses to carry out spiritual care, counseling efforts in improving knowledge, and continuous evaluation in carrying out spiritual care in the room.

\section{PENDAHULUAN}

Manusia dalam konsep paradigma keperawatan, dipandang sebagai individu yang utuh dan kompleks (mahluk holistik) yang terdiri dari bio- psiko-sosiospiritual. Manusia bertindak atau berprilaku secara verbal dan nonverbal, kadang-kadang dalam situasi tertentu, manusia dalam memenuhi kebutuhannya membutuhkan pertolongan, dan akan mengalami distress jika mereka tidak dapat melakukannya. Hal ini dijadikan dasar pernyataan bahwa perawat profesional harus berhubungan dengan seseorang yang tidak dapat menolong dirinya dalam memenuhi kebutuhannya (Budiono \& Pertami, 2015).

Menurut Cooper (2013) dalam penelitiannya mengatakan bahwa perawatan spiritual adalah komponen penting dari perawatan holistik. Di Australia, banyak perawat merasa mereka kurang siap untuk memberikan perawatan spiritual. Hal ini sebagian besar disebabkan kurangnya pendidikan perawatan spiritual yang disediakan dalam program keperawatan sarjana.

http://jurnalilmiah.stikescitradelima.ac.id/index.php/JI Vol.3,No.2, Januari 2020 
Beberapa rumah sakit diluar negeri telah melaksanakan spiritual care, Mahmoodishan, dkk (2010) melakukan penelitian di tiga rumah sakit di kota Gorgan, Iran, terhadap 20 orang perawat dan seluruhnya $(100 \%)$ perawat memiliki sikap yang positif terhadap spiritual care. Hasil ini diperkuat dengan penelitian Wong \& Lee (2008), dari 429 perawat di Rumah Sakit Hong Kong, $91 \%$ perawat menunjukkan pemahaman spiritual care yang memuaskan dan menyediakan spiritual care pada pasien.

Persepsi perawat terhadap nilai spiritual berkontribusi terhadap perkembangan kemampuan professional untuk memberikan asuhan spiritual (Arini, 2015). Hal ini senada dengan hasil penelitian Ozbasaran, dkk (2011) yang mengatakan bahwa persepsi perawat tentang spiritualitas dapat secara langsung mempengaruhi bagaimana mereka berperilaku, berurusan dengan pasien mereka dan berkomunikasi dengan mereka sehubungan dengan penyediaan perawatan spiritual. Ini berarti bahwa jika mereka percaya bahwa pemberian spiritual care adalah ibadah maka persepsi ini akan secara langsung mempengaruhi kemampuan mereka untuk mengatasi kebutuhan spiritual pasien.

Penelitian Chan (2010) mengatakan ada korelasi positif antara persepsi spiritual care dan praktik spiritual care di antara perawat, yang berarti bahwa semakin besar persepsi spiritual care perawat, maka spiritual care akan lebih sering disertakan dalam praktik perawat itu. Korelasi ini sangat penting dan bermakna karena dapat mendorong rumah sakit untuk meningkatkan kesadaran perawat tentang spiritual care untuk meningkatkan kualitas praktik spiritual care mereka.

Penelitian yang dilakukan oleh Hodge (2011) tentang kebutuhan spiritual pasien, dimana pasien mengungkapkan bahwa kebutuhan spiritual mereka adalah kebutuhan akan makna, tujuan dan harapan dalam hidup, hubungannya dengan Tuhan, praktek spiritual, kewajiban agama, hubungan interpersonal dan hubungan dengan staf profesional. Seseorang yang mengalami penderitaan, stres berat atau penyakit kronis, ketika ia telah berusaha maksimal dan tidak memperoleh hasil optimal dari usahanya, maka dia akan mencari kenyamanan dan kekuatan dari Tuhan (Yusuf, dkk 2017).
Memperhatikan besarnya peran aspek spiritual bagi kesehatan maka pemberian pelayanan spiritual merupakan hal yang penting yang perlu dilakukan oleh perawat. Perawat harus berupaya membantu memenuhi

kebutuhan spiritual pasien sebagai bagian dari kebutuhan menyeluruh pasien. Untuk menyelenggarakan pelayanan spiritual yang suportif dan penuh arti, penting bagi perawat untuk memahami konsep-konsep spiritualitas, kesejahteraan spiritual, kepercayaan, agama dan harapan. Setiap konsep menawarkan petunjuk dalam memahami pandangan yang dimiliki individu tentang kehidupan dan nilanilainya (Potter \& Perry, 2010).

Berdasarkan survei pendahuluan yang dilakukan oleh peneliti di Rumah Sakit Medika Stannia Sungailiat Bangka pada bulan Maret tahun 2018, ditemukan beberapa permasalahan dalam proses pelayanan spiritual care, antara lain spiritual care belum menjadi prioritas atau sering diabaikan dalam proses keperawatan, peran perawat dalam memenuhi kebutuhan spiritual care masih minim, persepsi dan pemahaman perawat dalam praktik keperawatan spiritual care masih kurang, pendokumentasian spiritual care dianggap menyita waktu perawat dan pasien belum mendapatkan pelayanan spiritual care yang optimal.

Dieksplorasi secara mendalam bagaimana persepsi perawat tentang spiritual care di ruang ICU Rumah Sakit Medika Stannia Sungailiat Kabupaten Bangka Tahun 2018.

\section{METODE}

Penelitian ini merupakan jenis penelitian kualitatif dengan pendekatan fenomenologi deskriptif. Penelitian ini telah dilaksanakan di Ruang Intensive Care Unit (ICU) Rumah Sakit Medika Stannia Sungailiat Kabupaten Bangka pada tanggal 7 Juni - 20 Juli 2018.

Informan dalam penelitian ini adalah 10 orang. Terdiri dari 8 orang informan utama yaitu perawat pelaksana ruang ICU Rumah Sakit Medika Stannia, serta 2 orang informan pendukung yaitu kepala bidang keperawatan serta kepala mutu dan etika keperawatan. Alat pengumpulan data yaitu pedoman wawancara, pedoman observasi, alat perekam, alat tulis. Metode pengumpulan data yaitu wawancara dan observasi. 
Teknik keabsahan data diperoleh melalui sebagai triangulasi sumber dan dan metode.

\section{HASIL DAN PEMBAHASAN}

Hasil Penelitian

\begin{tabular}{cccccc}
\multicolumn{7}{c}{ Tabel 1 } \\
Karakteristik Demografi Perawat \\
\hline No. & Jode & Jenis & Pendidikan & Masa \\
1. & Informan & Kelamin & Terakhir & Kerja \\
1. & Perawat Pelaksana & I1 & L & D3 & 4 tahun \\
2. & Perawat Pelaksana & I2 & P & D3 & 3 tahun \\
3. & Perawat Pelaksana & I3 & P & D3 & 1 tahun \\
4. & Perawat Pelaksana & I4 & L & D3 & 4 tahun \\
5. & Perawat Pelaksana & I5 & L & D3 & 4 tahun \\
6. & Perawat Pelaksana & I6 & P & D3 & 4 tahun \\
7. & Perawat Pelaksana & I7 & L & D3 & 4 tahun \\
8. & Perawat Pelaksana & I8 & P & D3 & 3 tahun \\
9. & Ka. Bid Keperawatan & T1 & P & S.Kep. Ners & 8 tahun \\
10. Ka. Mutu Keperawatan & T2 & P & S.Kep. Ners & 7 tahun \\
\hline
\end{tabular}

Hasil penelitian ini menemukan lima tema persepsi perawat tentang Spiritual care. Lebih rinci dapat dilihat pada tabel berikut ini :

Tabel 2

\begin{tabular}{|c|c|c|c|}
\hline $\mathrm{N}_{0}$ & Tema & Sub Tema & Kategori \\
\hline \multirow{3}{*}{1} & \multirow{3}{*}{$\begin{array}{l}\text { Pemahaman perawat tentang } \\
\text { Spiritual Care }\end{array}$} & Bimbingan & Layanan kerohanian \\
\hline & & Agama & Tentang keagamaan \\
\hline & & Kepercayaan & Tentang kepercayaan \\
\hline \multirow{2}{*}{2} & \multirow{2}{*}{$\begin{array}{l}\text { Cara perawat } \\
\text { mengidentifikasi kebutuhan } \\
\text { spiritual care pasien }\end{array}$} & $\begin{array}{l}\text { Menanyakan } \\
\text { agama kepercayaan }\end{array}$ & Agama kepercayan \\
\hline & & $\begin{array}{l}\text { Menanyakan pola ibadah } \\
\text { pasien }\end{array}$ & Praktek spiritual \\
\hline \multirow{3}{*}{3} & \multirow{3}{*}{$\begin{array}{l}\text { Pelaksanaan spiritual care } \\
\text { oleh perawat }\end{array}$} & Tidak terdokumentasi & Bukti tertulis tidak ada \\
\hline & & Folus perawatan fisik & Pemahaman \\
\hline & & Jarang dilakukan & Spiritual care tidak berjalan \\
\hline \multirow{4}{*}{4} & \multirow{4}{*}{$\begin{array}{l}\text { Berbagai hambatan dalam } \\
\text { pelaksanaan spiritual care }\end{array}$} & Kesulitan mengkaji pasien & Kesadaran pasien menurun \\
\hline & & Ambiqu beda agama & Perbedaan keyakinan \\
\hline & & Kurang pengetahuan & Sistem informasi \\
\hline & & Kurangnya fasilitas & Periengkapan \\
\hline \multirow{3}{*}{5} & \multirow{3}{*}{$\begin{array}{l}\text { Harapan terhadap spiritual } \\
\text { care }\end{array}$} & Meningkatkan pelayanan & $\begin{array}{l}\text { Implementasi SPO } \\
\text { bimbingan kerohanian }\end{array}$ \\
\hline & & Fasilitas dilengkapi & Pendukung layanan \\
\hline & & Meningkatkan kualitas SDM & Pengetahuan perawat \\
\hline
\end{tabular}

Lima Tema Persepsi Perawat tentang

Spiritual Care:

1. Pemahaman perawat tentang spiritual care

a. Bimbingan

Hasil penelitian ini didapatkan beberapa informan mengatakan bahwa spiritual care itu merupakan pemberian bimbingan rohani kepada pasien, sesuai dengan kutipan informan di bawah ini :

"Ee untuk spiritual care mungkin itu pelayanan tentang spiritual, " (I1)

“.....memberitahu keluarganya, ada formnya di ICU, terus untuk mengisi formnya, itu ada bimbingan kerohanian namanya." (I2)

"Spiritual care itu perawatan pasien selama dirawat tentang kegiatan kerohanianny, "(I3)
"Spiritual care itukan adalah misalnya pelayanan kerohanian bimbingan Kerohanian dijelaskan tentang kehidupan misalnya”.(I4)

“...bagaimana cara kita untuk eee me...membina kali, membina untuk sipasien... “.(I6)

“...menurut saya itu selain kita fisik yang kita obati kita juga me... mengobati jiwa,.... disitulah kita sebagai perawat nanti untuk mendorong dari segi kita medis dan spiritualnya juga...."(I7)

“...spiritual care itu dimana seorang perawat itu membantu seorang pasien dalam memenuhi eeee kebutuhan kerohanian...”. (I8)

b. Agama

Hasil penelitian ini didapatkan beberapa informan mengatakan bahwa spiritual care adalah tentang kegaamaan pasien, sesuai dengan kutipan informan di bawah ini :

"Spiritual itu tentang kegaamaan pasien...".(I2)

"Spiritual care menurut saya sebuah perawatan yang diberikan kepada pasien menganut eeee kepercayaan atau pun agama ke pasien”. (I5)

"...pemberian untuk eee menjelaskan untuk tentang agama ke pasien...”.'(I6)

c. Kepercayaan

Hasil penelitian ini didapatkan beberapa informan mengatakan bahwa spiritual care adalah tentang kepercayaannya pasien, sesuai dengan kutipan informan di bawah ini :

"Spiritual itu tentang kegaamaan pasien, pasien itu kepercayaannya apa...”.(I2)

"Spiritual care menurut saya sebuah perawatan yang diberikan kepada pasien menganut eeee kepercayaan atau pun agama dari pasien... kadang-kadang minta izin kekita, kita pun eeee memperbolehkan eee untuk pemberian jimat ataupun air-air”. (I5)

2. Cara perawat mengidentifikasi kebutuhan spiritual care pasien

a. Menanyakan agama/kepercayaan

Berdasarkan hasil penelitian yang telah dilakukan, informan mengemukakan bahwa cara mengidentifikasi kebutuhan spiritual care pasien adalah dengan menanyakan agama atau kepercayaan pasien, sesuai dengan kutipan informan di bawah ini :

“...Proses pengkajiannya pertama kali itu distatu itu ada, ada keterangan agamanya”.(I2)

http://jurnalilmiah.stikescitradelima.ac.id/index.php/JI Vol.3,No.2, Januari 2020 
“....kalau seandainya memang agamanya eee atau islam atau nonmuslim palingan kita angkat ke sesuai agama”.(I6)

"Kalau proses pengkajian disitu biasanyakan Cuma ditanyain tentang masalah agama....”.(I7)

Informan lain juga mengatakan bahwa cara mengidentifikasi kebutuhan spiritual care pasien adalah adalah dengan menanyakan kepercayaan pasien, sesuai dengan kutipan informan di bawah ini :

“....kalau pasien sadar kita tanya ke pasiennya kepercayaannya apa...”.(I8)

b. Menanyakan pola ibadah pasien

Berdasarkann hasil penelitian yang telah dilakukan, informan mengemukakan bahwa cara mengidentifikasi kebutuhan spiritual care pasien adalah menanyakan pola ibadah pasien, sesuai dengan kutipan informan di bawah ini :

“....kalau biasanya kebanyakan pola ibadahnya (pasien) berhenti”.(I1)

"....biasanya saya selama dinas di ICU pasien bertanya, suster ini jam berapa biasanya waktu saya solat, "..(I3)

"tentang beribadah pasien saat sakit, itukan kalau misalnya sakitkan di ICU kan pasiennya tidak bisa kita lakukan pengkajian untuk beribadahnya,". (I4)

"Pengkajiannya itu, misalnya kalo dalam kondisi sakit gitu apakah pasien masih bisa beribadah".(I5)

\section{Pelaksanaan spiritual care oleh perawat}

Tema pelaksanaan spiritual care oleh perawat terbentuk dari sub tema yaitu spiritual care tidak terdokumentasi, fokus pada perawatan fisik, dan spiritual care jarang dilakukan. Selanjutnya masingmasing sub tema akan diuraikan sebagai berikut :

a. Spiritual care tidak terdokumentasi

Berdasarkan hasil penelitian yang telah dilakukan, beberapa perawat mengemukakan bahwa pelaksanaan spiritual care oleh perawat belum terdokumentasi, sesuai dengan kutipan informan di bawah ini :

“......Kalau untuk segi tertulisnya sepertinya belum pernah kita lakukan, ’.(I1)

“...Pengkajian jalan dilakukan tapi tidak didokumentasikan masalah tidak pernah diangkat....Untuk diagnosa keperawatan yangsehubungan dengan spiritual care belum pernah diangkat.....". I2)

"Pengkajian jalan dilakukan tapi tidak didokumentasikan masalah tidak pernah diangkat....selama saya bekerja di rumah sakit Medika Stannia belum pernah kita melakukan askep tentang spiritual care terhadap pasien".'(I3)

"Untuk ee selama saya bekerja dirumah sakit medika stannia belum pernah kita melakukan askep tentang spiritual care terhadap pasien. (penelti menanyakan dokumentasi tentang askep spiritual care) belum $\underline{a d a}$ ". (I4)

"...yang didokumentasikan paling yang kayak formulir itu......(I5)

Hasil penelitian di atas didukung oleh hasil wawancara dengan informan triangulasi yang mengungkapkan bahwa selama ini evaluasi tentang pelaksanaan pelayanan spiritual care juga belum terdokumentasi. Berikut pernyataan dari 2 informan triangulasi tersebut :

"Untuk evaluasinya sih eee kita memang selalu ada pertemuan, pertemuan rutin salah satunya sih eee pertemuan rapat bulanan dan rapat eee bulanan karu kemudian rapat antar perawat juga biasanya kita menanyakan, cuma bentuk evaluasinya belum berbentuk yang tertulis, hanya menanyakan langsung apakah ada kendala dalam proses spiritual care tersebut."(T1)

"Untuk evaluasi secara dokumen belum, belum berjalan ee secara lisan ya."(T2)

Hasil penelitian di atas juga dipertegas dengan hasil observasi yang mendapatkan bahwa 5 informan selalu melakukan pengkajian kepada pasien yang masuk ruang ICU dengan mengisi format pengkajian, namun diagnosa keperawatan tidak pernah diangkat walaupun dalam hasil pengkajian tersebut ditemukan masalah spiritual, hal ini dibuktikan dengan tidak adanya dokumentasi keperawatan yang membahas tentang asuhan keperawatan spiritual di catatan terintergrasi pasien.

b. Fokus pada perawatan fisik

Berdasarkan hasil penelitian,beberapa perawat mengatakan bahwa pelaksanaan spiritual care oleh perawat tidak dilakukan karena fokus pada perawatan fisik, hal ini sesuai dengan kutipan berikut ini :

“.... kita tidak fokus ke spiritual care ya, kita fokusnya kediagnosa yang ada, "(I3)

http://jurnalilmiah.stikescitradelima.ac.id/index.php/JI Vol.3,No.2, Januari 2020 
“....Medika ini belum menerapkan askep spiritual care terhadap pasien, karena apa, mungkin bagi kami itu bukan diagnosa yang penting untuk diangkat".(I4)

"Ya, gimana ya karena kan kalo kita di ICU kan jadi kita lebih fokusnya kesitu (live saving), ”.(I5)

\section{c. Spiritual care jarang dilakukan}

Berdasarkan hasil penelitian, pelaksanaan spiritual care oleh perawat jarang dilakukan, hal ini sesuai dengan kutipan berikut ini :

"Belum pernah memanggil pemuka agama dari rumah sakit, kebanyakan keluarga pasien sendiri yang apa eeeee membawa atau tokoh agama”. (I1)

Dalam proses pelaksanaannya sebagian sudah dilakukan, sebagian lagi tidak".'(I2)

"(Spiritual care apakah dilaksanakan) Kadang-kadang iya kadang-kadang tidak, ". (I3)

“....Kalau misalnya untuk menanyakan kepada pasien mau solat atau mau minta pendoa atau pemuka agama, itu belum kita terapkan. (Peneliti menanyakan apakah pemuka agama rumah sakit pernah dihubungi) selama saya di ICU belum pernah. kami sebagai petugas menghubungi Humas untuk memanggil pemuka agama yang bekerja sama dengan rumah sakit".(I4)

"......(apakah pemuka agama pernah dipanggil untuk pelayanan kerohanian) sejauh ini sih belum ya, soalnya keluarga rata-rata mereka membawa sendiri....(Peneliti bertanya apakah diagnosa keperawatan tentang spiritual pernah diangkat) belum pernah".(I5)

"(pengkajian dilakukan kepasien) kadang iya kadang tidak... Belum pernah sih mungkin kita juga bingung mau mengangkat apa (tertawa). Kalau edukasi selama ini, selama di ICU kayaknya belum pernah untuk menganjurkan untuk solat, beribadah, ya itu tadi kita menyuruh untuk beristigfar, banyaknya itu”.(I6)

"....Kalau yang khusus ada sih kita form, ya cuma form itu terkadang kita perawat jarang, jarang untuk menawarkan tapi kalau saya ya, gak tau, saya kadangkadang, kadang- kadang saya menawarkan..... Untuk selama ini ya 4 tahun kita di ICU gak ada, kita gak pernah mengangkat cuma kalau saya pribadi cuma sering mengingatkan, ya mengingatkan aja, tapi kalau mengangkat kusus kayak kita mengangkat diagnosa yang lainnya tidak ada......meminta kita harus menawarkan seharusnya karena itu kan kebutuhan, tapi kebanyakan keluarga pasien itu mendatangkan pemuka agama sendiri-sendiri. Kalau selama diicu gak pernah, selama saya dinas ya....".(I7)

"....Belum ada (fasilitas yang mendukung untuk melaksanakan ibadah) jadi kalau misalnya untuk solat biasanya tayamum, biasanya di dinding tapi jarang. (perawat hanya sebatas mengingatkan saja) iya mengingatkan misalnya kalau pasien kalau mau tayamum.....biasanya ada juga keluarga yang meminta untuk pelayanan kerohanian, sebenarnya sih sesuai dengan SOP kita yang menawarkan untuk pelayanan kerohanian".(I8)

Hasil penelitian di atas juga didukung olehhasil observasi peneliti. Didapati bahwa 5 informan ini terkadang melakukan edukasi tentang sabar kepada pasien, memberi semangat, dan terkadang memfasilitasi keluarga pasien untuk mendo'akan pasien serta hanya 1 saja perawat yang melakukan komunikasi terapeutik kepada pasien. Namun, sekalipun implementasi-implementasi keperawatan tersebut dilakukan, tidak ada dokumentasi tertulis di catatan perkembangan terintegrasi pasien.

4. Berbagai hambatan dalam pelaksanaan spiritual care

Tema berbagai hambatan dalam pelaksanaan spiritual care terbentuk dari sub tema yaitu kesulitan mengkaji pasien dengan penurunan kesadaran, ambiqu/beda agama, kurang pengetahuan dan kurangnya fasilitas. Selanjutnya sub tema akan diuraikan sebagai berikut :

a. Kesulitan mengkaji pasien dengan penurunan kesadaran

Berdasarkan hasil penelitian yang telah dilakukan, informan mengemukakan bahwa salah satu hambatan dalam pelaksanaan spiritual care adalah adalah adanya kesulitan mengkaji pasien dengan penurunan kesadaran, hal ini sesuai dengan kutipan informan di bawah ini :

"Eee karena itu tidak bisa dilakukan untuk kesemua pasien diruang ICU, karenakan untuk pasien yang tidak sadar....".(I1)

"Hambatan lain yang dihadapi adalah kesadaran pasien, ".(I2)

"Hambatan mungkin ada kalau dengan pasien suster gimana ginigini kita mungkin kondisi pasien. .'.(I3)

"(Peneliti menanyakan hambatan lainnya) Kalau misalnya hambatan apa ya, mungkin kondisi pasiennya, ....".(I4)

“....Mungkin kita beranggapan karena, gimana ya, si pasien nya sakit kali ya terus....”.(I6)

http://jurnalilmiah.stikescitradelima.ac.id/index.php/JI Vol.3,No.2, Januari 2020 
b. Ambiqu/beda agama

Berdasarkan hasil penelitian yang telah dilakukan, informan mengemukakan bahwa hambatan lain dalam pelaksanaan spiritual care adalah beda agama, hal ini sesuai dengan kutipan informan di bawah ini :

"Eee karena itu tidak bisa dilakukan untuk kesemua pasien diruang ICU, karenakan untuk pasien yang tidak sadar eee bedanya keyakinan atau pun beda beda apa agama misalnya....”.(II)

“....terus kendalanya kalopun dari keperawatan juga yang tadi kalo misalnya yang beda agama gitu... ".(I5) “.....Masalah, ada sih kalau masalah ya itu tadi, kalau misalnya untuk, mungkin agamanya karena kita agamanya muslim, kita lebih mengerti mau kemana arahnya".(I6)

"Kita muslim tapi pasien yang kita hadapi itu non muslim istilahnya kan, kadang-kadang kita bingung mereka ini sistemnya bagaimana”.(I7)

\section{c. Kurang pengetahuan}

Berdasarkan hasil penelitian yang telah dilakukan, informan mengemukakan bahwa hambatan lain dalam pelaksanaan spiritual care adalah kurang pengetahuan, hal ini sesuai dengan kutipan informan di bawah ini :

"(Peneliti menanyakan mengapa pelayanan kerohanian tidak berjalan sesuai SOP) Tidak pernah diinformasikan menurut saya mungkin eeeeee apa sudah kebiasaan mungkin, keluarga bisa mencari sendiri...lalu kita menginformasikan ke SDM untuk memanggil tokoh agama".(I1)

Form yang dimaksud adalah form kalau yang kayak askep itu, kan ada itu form-formnya.kalau disini ada form tentang penyakit aja, form kerohanian setau saya belum ada.....Pelayanan kerohanian belum berjalan sesuai sop, sop pelayaan kerohaniaan itu ......tidak ingat, untuk pembimbing kerohanian sudah disediakan untuk semua agama...."(I2)

(Peneliti menanyakan SOP pelayanan kerohanian) biasanya kita panggilkan keluarganya dulu terus kita, aduh kurang tau juga saya cuma sudah SOPnya cuma jarang dibaca gitu (tertawa) isi form aja.... Cuma kita sampaikan pak gimana tayamum aja. (peneliti menegaskan kembali jawaban informan) tidak tau apa yang mau disediain pokoknya tayamum aja”.,(I3)

"Ya, gimana ya karena kan kalo kita di ICU kan jadi kita lebih fokusnya kesitu (live saving), maksudnya ke bentuk live savingnya aja, kalo ke yang itu kadangkadang sama sekali gak kepikiran kita”.'I5)
"(Peneliti menanyakan belum dijalankan kenapa) ya eeee (tertawa bingung) perawatnya eee (tertawa), perawatnya malas kali ya.... Mungkin diagnosa itu ada kali ya, mungkin saya aja yang belum pernah baca".(I6)

"Ya terkadang gimana ya saya juga bingung ya karena pertama, pertama emang mungkin kurang pengetahuan ya....kadang-kadang kita menurut saya juga tidak tau apakah harus menggunakan air atau proses yang lainnya untuk bersucinya....".(I7)

\section{d. Kurangnya fasilitas}

Berdasarkan hasil penelitian yang telah dilakukan, informan mengemukakan bahwa hambatan lain dalam pelaksanaan spiritual care adalah kurangnya fasilitas, hal ini sesuai dengan kutipan informan di bawah ini :

"Kalau untuk fasilitas gak ada kalu untuk fasilitas tayamum, paling kita apa minta edukasi untuk tayamum dibed pasien sendiri. Prosenya ini tidak tidak terdokumntasi....".(I1)

"Cuma itu aja yang ada formnya yang lain itu tidak ada, apa mungkin saya belum tau ada atau tidaknya, tapi sepengetahuan saya selama ini belum ada".(I2)

"Disini tidak ada fasilitas tayamum, tidak ada....”.(I3) “.....untuk sementara ini belum ada misalnya fasilitas kerohanian atau fasilitas untuk solat bagi pasien yang beragam islam dirumah sakit."(I4)

"(Peneliti bertanya tentang fasilitas yang mendukung spiritual care) sebenarnya sih, gimana ya untuk fasilitasnya mungkin sebagian udah ada".(I5)

“.....cuma saya terkadang mau menawarkan misalnya yang tadi ya rumah sakit juga tidak menyediakan fasilitasnya jadi saya serba bingung mau nya gimana. "(I7)

"Belum ada (fasilitas yang mendukung untuk melaksanakan ibadah) jadi kalau misalnya untuk solat biasanya tayamum, biasanya di dinding tapi jarang. belum ada itunya sih diagnosa keperawatan tentang spiritual care itu kan kalo dari format pengkajiannya sudah ada kan spiritual care kayak disini ada agama, perubahan pola ibadah setelah sakit, sebenarnya disini sudah kuat untuk data pendukungnya....Fasiltas termasuk hambatan"..(I8)

Hasil penelitian di atas sejalan dengan hasil wawancara peneliti dengan informan triangulasi yang menyatakan bahwa diagnosa keperawatan tentang spiritual care belum masuk dalam daftar Standar Asuhan Keperawatan (SAK). Pernyataan ini terlihat dalam kutipan wawancara berikut ini :

http://jurnalilmiah.stikescitradelima.ac.id/index.php/JI Vol.3,No.2, Januari 2020 
"Cuma kalau memang yang spiritual care kayaknya belum, kayaknya itu kekhusus ya, kalau kita inikan karena menyusun SAK itu (Standar Asuhan Keperawatan) itu berdasarkan 10 penyakit terbanyak, jadi ke spiritual care ini belum. "(T1)

Hasil wawancara dengan triangulasi kepala mutu dan etika keperawatan ditemukan masalah lain di luar sub tema yang ada, hambatan dalam pelaksanaan spiritual care menurut beliau karena kesibukan perawat atau banyaknya pekerjaan perawat yang tidak sebanding dengan pasien yang dirawat. Adapun pernyataannya adalah sebagai berikut:

"Dari perawat itu sendiri, banyaknya pekerjaan perawat itu sendiri sehingga apa yang harus dikerjakan lalai, lupa untuk dikerjakan. Sebenarnya bisa jadi hambatan karena sebenarnya perawat sudah mengetahui, karena dia sibuk dengan kesibukan pekerjaan perawat yang tidak sebanding dengan pasien yang dirawat itu hambatan. "(T2)

\section{Harapan terhadap spiritual care}

Tema harapan terhadap spiritual care terbentuk dari beberapa sub tema yaitu meningkatkan pelayanan, fasilitas dilengkapi, adanya dukungan atasan serta meningkatkan kualitas SDM. Selanjutnya sub tema akan diuraikan sebagai berikut :

\section{a. Meningkatkan pelayanan}

Berdasarkan hasil penelitian yang telah dilakukan, informan mengemukakan bahwa harapan terhadap spiritual care adalah pelayanan yang berkaitan dengan spiritual care ditawarkan atau diedukasikan, hal ini sesuai dengan kutipan informan di bawah ini : "Mungkin yang sebelumya gak pernah ditawarkan dari awal pasien masuk keruangan ICU mungkin untuk selanjutnya ditawarkan atau diedukasikan untuk pelayanan spiritual carenya misalnya pokoknya setiap pasien masuk yang sadar ataupun tidak sadar”.(I1)

"Untuk rumah sakit diharapkan untuk pembimbing kerohanian itu diadakan terus setiap hari, setidaknya itu bergantian, misal agama islam hari senin, agama kristen hari selasa, agama yang lain itu ada hariharinya, jadi walaupun yang satu ini gak ketemu dengan pembimbingnya, mungkin besoknya akan ketemu itu berlaku untuk semua ruangan"..I2)

“.....setiap pagi biasanya ada eee ustad atau apa yang datangi tiap pasien untuk bantu doa atau apa, diajak eee pasien itu diajak istilahnya berdoa untuk mengingat yang diatas ....”.'(I5)
Pernyataan di atas juga didukung oleh informan lainnya yang mengatakan bahwa harapan terhadap spiritual care adalah bimbingan kerohanian berjalan sesuai dengan SOPnya, hal ini sesuai dengan kutipan berikut ini :

“....berharap bimbingan kerohanian berjalan sesuai SPOnya”.(I5)

"....misalnya dari petugas kita itu misalnya menyediakan lebih aktif lagi misal untuk petugaspetugas...."(I8)

Pernyataan informan triangulasi juga mendukung pernyataan di atas, yaitu perlunya evaluasi kegiatan spiritual care agar pelayanan ini dapat ditingkatkan. Berikut adalah ungkapan yang diberikan oleh triangulasi tersebut :

"Eee (berfikir) yang kita upayakan memang, saya sih kepengen kedepannya ini kan kita sudah ada di bawah saya sekitar 2 bulan yang lalu sudah ada sub mutu dan etika keperawatan, memang beliau rencananya akan mengevaluasi kegiatan spiritual care sampai dimana sih eeee sudah dikerjakan...." (T1)

".... Kedepannya nanti mudah- mudahan kalau sudah ada asuhan keperawatan tentang spiritual care itu akan kita tingkatkan dan untuk evaluasinya kita akan selalu control dan menanyakan teman-teman untuk hambatan maupun pelaksanaannya seperti apa."(T1)

\section{b. Fasilitas dilengkapi}

Berdasarkan hasil penelitian yang telah dilakukan, informan mengemukakan bahwa harapan terhadap spiritual care adalah fasilitas dilengkapi dan formulir pendukung untuk asuhan keperawatan, hal ini sesuai dengan kutipan informan di bawah ini :

“..... Terus ada dokumentasinya dan juga ada askep untuk perawat, terus ada pengkajian khususnya juga untuk spiritual care ini"”.(I1)

“....jika emang itu suatu asuhan yang penting ya paling kita harus menyediakan fasilitas, fasilitas mungkin yang ya bagi pasien yang mau melaksanakan ibadah di tempat tidur...askep tentang spiritual carenya ya harus membuat pengkajian yang lebih spesifik agar bisa ya kita terapkan kepada pasiennya...”.(I4)

"Untuk rumah sakit harapannya ada ee ya dari mungkin dari pemasaran atau gak dari humas, jadi dari rumah sakit itu harus keruangan-ruangan kali ya biar eee ngasih tau ke perawat ....". (I6)

"tolong ya difasiltas tayamum itu masing-masing ruangan terutama di ICU diadakan..... Kalau bisa pemuka agama yang ada dipertemukan dengan karyawan yang ada disini, terus bisa bertanya apa sih

http://jurnalilmiah.stikescitradelima.ac.id/index.php/JI Vol.3,No.2, Januari 2020 
yang perlu kami informasikan yang kami ibaratnya kasih ilmu atau terutama tadi solat, apalagi kita kan wajib solat lima waktu kan”.(I7)

Harapan dari hasil penelitian di atas juga sejalan dengan pernyataan informan triangulasi yang berencana menyediakan asuhan keperawatan spiritual care. Berikut ungkapannya :

"Kedepannya nanti mudah- mudahan kalau sudah ada asuhan keperawatan tentang spiritual care itu akan kita tingkatkan dan untuk evaluasinya kita akan selalu control dan menanyakan teman-teman untuk hambatan maupun pelaksanaannya seperti apa."(T1)

\section{c. Meningkatkan kualitas SDM}

Berdasarkan hasil penelitian yang telah dilakukan, informan mengemukakan bahwa harapan terhadap spiritual care adalah rumah sakit mengadakan pelatihan dalam memberikan spiritual care kepada pasien, hal ini sesuai dengan kutipan informan di bawah ini :

"Harapan saya untuk rumah sakit mengadakan pelatihan untuk cara spiritual care untuk agamaagama selain yang saya anut'.(I2)

“....kepada pasien paling nanti ya kita koordinasi dengan bidang keperawatan kalau mau melakukan apa mau diambil askep tentang spiritual carenya ya harus membuat pengkajian yang lebih spesifik agar bisa ya kita terapkan kepada pasien”.(I4)

"Untuk rumah sakit harapannya ada ee ya dari mungkin dari pemasaran atau gak dari humas, jadi darirumah sakit itu harus keruangan-ruangan kali ya biar eee ngasih tau ke perawat atau kalau gak itu, menanyakan juga sih ke pasien, kalau misalnya mau memakai (pemuka agama) dari rumah sakitnya....Paling untuk kedepannya juga ee perawat ICU mungkin lebih dijelasin tentang harusnya kayak gimana biar bisa menjalankan juga untuk pengkajiannya".(I6)

"Kalau bisa pemuka agama yang ada dipertemukan dengan karyawan yang ada disini, terus bisa bertanya apa sih yang perlu kami informasikan yang kami ibaratnya kasih ilmu atau terutama tadi solat, apalagi kita kan wajib solat lima waktu kan...... Harapan kedepan ya lebih baik lagi, bukan hanya untuk pasien tapi juga untuk bagi perawatnya juga ya di ruangan ICU...." "Kalau bisa pemuka agama yang ada dipertemukan dengan karyawan yang ada disini, terus bisa bertanya apa sih yang perlu kami informasikan yang kami ibaratnya kasih ilmu atau terutama tadi solat, apalagi kita kan wajib solat lima waktu kan".(I7)
"Perlu diadakan untuk pelatihannya, karena salah satu untuk memenuhi kebutuhan kerohanian pasien, apalagi dalam keadaan-keadaan kritis"”.(I8)

Berdasarkan hasil observasi dengan menggunakan lembar observasi yang ada, didapatkan hasil dari 8 informan hanya 5 informan yang bisa dilakukan observasi. Hal ini dikarenakan dari 8 pasien yang masuk melalui IGD terdapat 3 pasien diterima oleh informan yang sudah pernah dilakukan observasi sebelumnya. Observasi dihentikan karena sudah masuk batas akhir penelitian.

\section{Pembahasan}

1. Pemahaman perawat tentang spiritual care

a. Bimbingan kerohanian

Persepsi informan dalam penelitian ini mengungkapkan bahwa spiritual care adalah perawatan yang berhubungan dengan pelayanan spiritual, yang berbentuk bimbingan kerohanian dimana perawat berperan sebagai fasilitator dan juga ikut terlibat bersama pemuka agama dalam menenangkan pasien, memotivasi pasien, memberikan edukasi kepada pasien untuk bersabar dalam menghadapi penyakitnya.

Menurut Vaughans (2013) spiritualitas adalah konsep abstrak yang paling baik yang didefinisikan secara individu. Meski banyak variasi bagaimana spiritualitas didefinisikan, kebanyakan setuju bahwa tema pokoknya dikaitkan dengan cara seseorang mengkarakteristikkan kualitas hidup mereka dan juga tujuan hidup mereka. Hal ini juga sumber daya yang digunakan untuk memandu kehidupan sehari-hari, memandu interaksi dengan orang lain dan mendorong perasaan aman, selamat, kekuatan dan harapan, khususnya selama kritis.

Hasil temuan di atas sejalan dengan pendapat Mahmoodishan, dkk (2010) dalam penelitiannya mengatakan bahwa spiritual care berfokus pada menghormati pasien, interaksi yang ramah dan simpatik, mendengarkan dengan penuh perhatian dan memberikan kekuatan pada pasien dalam menghadapi penyakitnya.

b. Agama

Sebagian informan dalam penelitian ini mempersepsikan spiritual care sebagai perawatan yang 
diberikan oleh perawat kepada pasien yang berhubungan dengan agama.

Agama terbatas pada perasaan keyakinan yang dipelajari dan dipercaya, mempunyai ciri khas sesuai kitab suci yang diajarkan, terdapat penerapan ritual keagamaan, penggunaan dan penerapan ajaran agama dalam kehidupan bermasyarakat dan menjadi panduan dalam membangun semangat ketika sakit dan mencari pengobatan (puasa, sholat, meditasi dan sebagainya) (Yusuf, dkk, 2017).

Spiritualitas dan agama adalah sesuatu yang berbeda. Spiritualitas banyak diartikan sebagai saripati, pusat, inti, dimensi integrasi. Dimensi ini sering diartikan sebagai domain of life, yang membawa signifikansi, tujuan, arti dan arah kehidupan seseorang. Spiritual menurut kamus besar bahasa Indonesia adalah berkenaan dengan kejiwaan, berhubungan dengan rohani. Region berasal dari akar kata to limb together, sehingga secara definitif agama mengacu pada agregasi komunitas dimana para pengikutnya mempertahankan sense of belonging melalui keyakinan, ibadah, pengajaran etik dan tradisi keagamaan (Bessing, 2010 dalam Yusuf, dkk, 2017). Spiritual berbeda dengan religi dan dimensi psikologi, tetapi dipengerahuhi oleh kebudayaan (Sari \& Muin, 2009).

\section{c. Kepercayaan}

Informan lain mengungkapkan bahwa spiritual care adalah tentang kepercayaan pasien. Menurut Fowler (1995 dalam Yusuf, dkk, 2017) kepercayaan bersifat universal, dimana merupakan penerimaan individu terhadap kebenaran yang tidak dapat dibuktikan dengan dengan pikiran yang logis. Kepercayaan dapat memberikan arti hidup dan kekuatan bagi individu ketika mengalami kesulitan dan stress.

Pernyataan informan ini sejalan dengan pendapat Hidayat \& Uliyah (2014) mengatakan bahwa spiritual (spirituality) merupakan sesuatu yang dipercayai oleh seseorang dalam hubungannya dengan kekuatan yang lebih tinggi (Tuhan), yang menimbulkan suatu kebutuhan serta kecintaan terhadap adanya Tuhan, dan permohonan maaf atas segala kesalahan yang telah diperbuat.

Bila disimpulkan, menurut peneliti secara umum pemahaman informan tentang spiritual care di atas memang sudah sesuai dengan teori dan penelitian terkait jika ketiga sub tema yang ada digabungkan, yang berarti bahwa informan memamahmi makna spiritual care itu sendiri. Namun apabila sub tema dan rincian wawancara tersebut dikembalikan ke masingmasing informan, maka akan terlihat bahwa secara individu pemahaman para informan masih belum sesuai dengan teori yang ada. Sebagai contoh, hal ini dapat kita lihat dari hasil wawancara I2, I3, dan I4 yang mengatakan bahwa spiritual care sama dengan bimbingan kerohanian (pelayanan kerohanian). Pemahaman seperti ini tidaklah tepat menurut peneliti, karena bimbingan kerohanian (pelayanan kerohanian) berdasarkan SPO yang ada dilakukan oleh pemuka agama yang disediakan oleh rumah sakit, bukan oleh perawat. Padahal jika kita kembali kemakna spiritual care menurut beberapa sumber, spiritual care dapat diartikan sebagai kegiatan dalam keperawatan yang berfokus pada menghormati pasien untuk membantu pasien dalam menghadapi penyakitnya dengan sikap dan tindakan praktek keperawatan berdasarkan nilainilai keperawatan spiritual yaitu mengakui martabat manusia, kebaikan, interaksi yang ramah dan simpatik, belas kasih, ketenangan serta kelemahlembutan. Jika para informan beranggapan seperti di atas maka peran perawat sebagai pemberi asuhan keperawatan dan fungsi independen perawat akan digantikan oleh pemuka agama. Peneliti menganggap bahwa pelayanan kerohanian adalah salah satu bentuk kolaborasi perawat dalam memberikan asuhan keperawatan kepada pasien dengan masalah spiritual.

Temuan dari para informan lainnya yaitu spiritual care adalah perawatan yang berhubungan dengan agama dan kepercayaan. Jika pemahaman para informan membatasi pengertian spiritual care seperti ini, menurut peneliti, peran perawat hanya sebatas memfasiltasi pasien dalam penerapan kepercayaan dan ritual keagamaan saja. Padahal menurut penelitian Hodge (2011) enam kebutuhan spiritual pasien, yaitu : (1) makna, tujuan, dan harapan hidup, (2) hubungan dengan Tuhan, (3) praktek spiritual, (4) kewajiban agama, (5) hubungan interpersonal, (6) hubungan dengan perawat dan tenaga kesehatan lainnya. Jadi jelas bahwa makna spiritual care itu luas, mencakup ke tiga sub tema temuan dalam penelitian ini.

2. Perawat dapatmengidentifikasi kebutuhan spiritual pasien

Informan dalam penelitan ini mengungkapkan bahwa cara mengidentifikasi kebutuhan spiritual pasien adalah dengan cara melihat kondisi pasien selanjutnya menanyakan agama

http://jurnalilmiah.stikescitradelima.ac.id/index.php/JI Vol.3,No.2, Januari 2020 
atau kepercayaan apa yang dianut pasien, apakah ada perubahan pola ibadah pasien saat sakit dan apakah pasien membutuhkan pendo'a. Persepsi informan ini walaupun terbilang kurang lengkap, namun sudah sejalan dengan pendapat Yusuf, dkk (2017) yang mengatakan bahwa pengkajian riwayat keperawatan difokuskan pada sejauh mana keyakinan spiritual mempengaruhi kehidupan terkait penyakit yang dialami saat ini, bagaimana bentuk dukungan spiritual oleh tenaga kesehatan yang diinginkan klien, bagaimana cara memenuhi kebutuhan spiritual selama sakit, apakah memerlukan konsultan spiritual, rohaniawan dan bagaimana harapan klien dengan penyakitnya. Selain berbagai pertanyaan di atas, perawat perlu mengobservasi terkait lingkungan, perilaku, verbalisasi klien, sikap dan perasaan serta hubungan interpersonal yang ditampakkan klien.

Pendapat lain mengatakan bahwa pasien ternyata persepsinya lebih luas dibandingkan dengan persepsi perawat. Sehingga perawat harus mampu mengkaji lebih dalam lagi hal-hal apa saja yang dibutuhkan oleh pasien untuk memenuhi kebutuhan spiritualnya (Ariyani, Suryani, \& Nuraeni, 2014).

Pemahaman informan pada tema yang pertama, ternyata mempengaruhi tema yang kedua ini. Menurut peneliti, dikarenakan pemahaman yang tidak komprehensif, dampak yang dirasakan adalah para informan tampak kesulitan saat akan melakukan pengkajian ke pasien terkait kebutuhan spiritualnya. Hal ini dapat terlihat dari penguasaan format pada pengkajian kebutuhan spiritual yang sudah disediakan rumah sakit. Para informan hanya mengingat dua sub tema dalam melakukan pengkajian yaitu menanyakan agama/kepercayaan dan menanyakan pola ibadah pasien. Sebagian informan beralasan bahwa format pengkajian yang ada belum lengkap dan spesifik. Padahal berdasarkan hasil observasi peneliti terhadap format pengkajian yang ada, format tersebut sebenarnya sudah bisa mewakili kebutuhan spiritual pasien, karena sudah sesuai dengan pedoman pengkajian menurut Craven (1995 dalam Hamid, 2008).

3. Pelaksanaan spiritual care

a. Spiritual care tidak terdokumentasi

Pada penelitian ini informan juga mengatakan bahwa selain tidak pernah mengangkat asuhan keperawatan yang berhubungan dengan spiritual care, perawat juga tidak melakukan dokumentasi untuk tindakan-tindakan yang mengarah ke implementasi spiritual care walaupun sudah dilakukan, hanya pengkajian saja yang dilakukan dokumentasi karena memang sudah terdapat dalam formulir pengkajian. Informasi dari informan triangulasi juga menyatakan bahwa selama ini evaluasi tentang pelaksanaan pelayanan spiritual care belum terdokumentasi. Hasil observasi penelitian juga mengungkapkan bahwa namun diagnosa keperawatan tidak pernah diangkat walaupun dalam hasil pengkajian tersebut ditemukan masalah spiritual, hal ini dibuktikan dengan tidak adanya dokumentasi keperawatan yang membahas tentang asuhan keperawatan spiritual di catatan terintergrasi pasien.

Hasil penelitian di atas sesesuai dengan hasil penelitian Baldacchino (2006, dalam Sianturi, 2016) yang menemukan bahwa jika perawat melakukan kegiatan spiritual care, jenis dan frekuensi dari intervensi tidak diketahui karena spiritual care jarang bahkan tidak pernah didokumentasikan. Pendapat ini didukung dengan penelitian Cavendish (2003, dalam Sianturi : 2016) mengatakan bahwa jika perawat menyediakan spiritual care, tetapi tidak didokumentasikan atau mungkin perawat sudah memberikan spiritual care dan sudah melakukan pendokumentasian tetapi dokumentasi hilang.

b. Fokus pada perawatan fisik

Mayoritas informan dalam penelitian ini mengakui bahwa mereka lebih fokus melakukan pengkajian dan perawatan fisik bahkan salah satu informan mengatakan bahwa diagnosa keperawatan yang berhubungan dengan spiritual care bukanlah diagnosa yang penting, sehingga mengabaikan pelaksanaan spiritual care.

Pendapat ini sejalan dengan penelitian yang dilakukan oleh Cavendish et al (2003, dalam Sianturi : 2016) yang mengatakan bahwa perawat lebih fokus melakukan perawatan domain fisik daripada spiritual care. Khoiriyati (2008) juga menuturkan namun kenyataannya kebutuhan spiritual dan psikososial kurang menjadi hal yang prioritas daripada kebutuhan fisik karena kebutuhan tersebut seringkali abstrak, kompleks dan lebih sulit untuk diukur.

c. Spiritual care jarang dilakukan

http://jurnalilmiah.stikescitradelima.ac.id/index.php/JI Vol.3,No.2, Januari 2020 
Berdasarkan hasil dari penelitian ini, informan mengatakan bahwa spiritual care jarang diberikan karena informan menganggap bukan fokus utama keperawatan. Padahal banyak studi menunjukkan bahwa spiritualitas memegang peranan penting dalam kehidupan manusia dan adanya hubungan yang positif antara spiritual care dan kesembuhan pasien, tetapi spiritual care masih sulit untuk dilaksanakan Hal ini sejalan dengan penelitian Wong (2008) yang mengatakan bahwa mayoritas perawat jarang melakukan spiritual care pada praktek keperawatan.

Temuan peneliti pada tema yang ketiga ini semakin memastikan bahwa para informan memahami spiritual care tidak sebagai salah satu kebutuhan holistic pasien. Peneliti melakukan observasi dengan panduan lembar observasi yang ada tanpa diktetahui oleh para informan. Berdasarkan lembar observasi tersebut, disimpulan bahwa tidak satupun para informan melakukan pengkajian langsung ke pasien ataupun keluarga pasien terkait kebutuhan spiritual. Bahkan dalam agama/kepercayaan pasien, para informan tidak langsung bertanya. Diketahuinya agama/kepercayaan pasien biasanya berdasarkan kartu identitas pasien atau melihat dari penampilan keluarga pasien, misalnya keluarga pasien, istri atau anak pasien memakai hijab, maka informan menganggap agama pasien adalah islam.

Untuk tindakan keperawatan, memang sebagian besar sudah melakukan edukasi kepada pasien dengan mengajak pasien beristigfar bagi yang beragama islam, agar sabar menghadapi penyakitnya, menenangkan pasien-pasien yang terkadang tampak gelisah, memberikan fasilitas misalnya kursi kepada keluarga pasien yang akan membacakan do'a dan sebagainya. Namun tindakan keperawatan tersebut seakan-akan tidak pernah dilakukan para informan karena dokumentasinya tidak ada. Dokumentasi keperawatan adalah bukti bahwa perawat melakukan perannya dalam memberikan asuhan keperawatan kepada pasien. Saat dokumentasi tidak dilakukan, maka asuhan keperawatan tidak ada. Jika asuhan keperawatan tidak ada maka perawat sudah menyalahi fungsinya.

4. Berbagai hambatan dalam pelaksanaan spiritual care a. Kesulitan mengkaji pasien dengan penurunan kesadaran

Informan dalam penelitian ini mengatakan bahwa mereka merasa kesulitan dalam melakukan pengkajian pada pasien dengan penurunan kesadaran ataupun gelisah, sehingga spiritual care tidak bisa dilakukan pada semua pasien. Pendapat ini sejalan dengan Hamid (2008) konsep spiritual dalam keperawatan sudah menjadi dasar dalam sejarah keperawatan namun dalam prakteknya seringkali diabaikan. Asuhan keperawatan yang diberikan oleh perawat tidak bisa terlepas dari aspek spiritual yang merupakan bagian integral dari interaksi perawat dengan pasien. Ketika memberikan asuhan keperawatan kepada pasien, harusnya perawat peka terhadap kebutuhan spiritual pasien, tetapi dengan berbagai alasan ada kemungkinan perawat justru menghindar untuk memberikan asuhan spiritual.

\section{b. Ambiqu/beda agama}

Berdasarkan hasil penelitian ini, beberapa informan mengungkapkan bahwa mereka bingung saat menghadapi pasien dengan agama yang berbeda, pernyataan ini masih konsisten dengan hasil penelitian Mc Sherry (2006 dalam Sianturi, 2016) Ambigu muncul ketika perawat berbeda keyakinan dengan pasien yang dirawatnya. Hal ini dapat mengakibatkan rasa tidak aman, sehingga perawat menghindar dari keadaan ini. Ambigu mencakup kebingungan perawat, takut salah, dan menganggap spiritual terlalu sensitif dan merupakan hak pribadi pasien.

Sementara itu menurut Zehtab \& Hajbaghery (2014) pola praktik perawat dibidang perawatan spiritual dapat dikelompokkan menjadi dua kategori termasuk intervensi agama dan nonreligius. Intervensi agama termasuk mengobati keyakinan agama pasien tanpa prasangka, memberi mereka kesempatan untuk berhubungan dengan Tuhan dan mengekspresikan nilai-nilai dan keyakinan mereka, membantu mereka mempraktekkan agama mereka, dan merujuk mereka kepada para pemimpin ulama dan agama.

Intervensi nonreligius termasuk kehadiran perawat untuk pasien dan keluarga mereka, membuat kontak mata langsung ketika berkomunikasi dengan pasien, bersimpati dengan pasien dan keluarga mereka, mendengarkan pasien dan keluarga mereka dengan penuh perhatian, dan memiliki cinta dan antusiasme untuk pasien.

\section{c. Kurang pengetahuan}

Beberapa informan dalam penelitian ini juga mengakui bahwa mereka kurang pengetahuan dan terkadang tidak terpikirkan tentang spiritual care karena jarang diinformasikan sehingga mereka tidak tahu apa yang harus dilakukan terkait spiritual care.

http://jurnalilmiah.stikescitradelima.ac.id/index.php/JI Vol.3,No.2, Januari 2020 
Ditemukan juga bahwa beberapa informan tidak mengetahui alur SOP pelayanan kerohanian yang sudah ditetapkan rumah sakit. Padahal menurut teorinya, perawat harus berupaya membantu memenuhi kebutuhan spiritual pasien sebagai bagian dari kebutuhan menyeluruh pasien.

Untuk menyelenggarakan pelayanan spiritual yang suportif dan penuh arti, penting bagi perawat untuk memahami konsep-konsep spiritualitas, kesejahteraan spiritual, kepercayaan, agama dan harapan. Setiap konsep menawarkan petunjuk dalam memahami pandangan yang dimiliki individu tentang kehidupan dan nila-nilainya (Potter \& Perry, 2010).

Persepsi perawat terhadap nilai spiritual berkontribusi terhadap perkembang kemampuan profesional untuk memberikan asuhan spiritual (Arini, 2015). Menurut Cooper (2013) dalam penelitiannya mengatakan bahwa perawatan spiritual adalah komponen penting dari perawatan holistik. Di Australia, banyak perawat merasa mereka kurang siap untuk memberikan perawatan spiritual. Hal ini sebagian besar disebabkan kurangnya pendidikan perawatan spiritual yang disediakan dalam program keperawatan sarjana.

\section{d. Kurangnya fasilitas}

Sebagian besar informan mengungkapkan bahwa fasilitas yang disediakan oleh rumah sakit belum ada terutama untuk pasien yang beragama islam, sehingga terkadang mereka kebingungan saat akan membantu pasien dalam praktek spiritual. Selain itu, ditemukan juga bahwa fasilitas formulir diagnosa keperawatan tentang spiritual care belum dimasukkan ke dalam SAK (Standar Asuhan Keperawatan) menurut Ka. Bid Keperawatan, sehingga pelaksanaan spiritual care tidak maksimal. Padahal menurut Hodge (2011) pasien mempunyai keinginan untuk terlibat dalam kegiatan ibadah secara rutin. Dengan kegiatan ibadah pasien berharap dapat meningkatkan hubungan dengan Tuhan sehingga dapat mengatasi segala cobaan yang mereka hadapi. Kegiatan yang dilakukan oleh pasien adalah berdo'a, membaca kitab suci, pelayanan keagamaan, mendengar musik rohani dan membaca buku yang bertema rohani.

Pada tema yang keempat ini, peneliti menyimpulkan bahwa munculnya empat sub tema di atas adalah akibat kurangnya informasi mengenai cara memenuhi kebutuhan spiritual care dan pentingnya pemenuhan spiritual care di rumah sakit. Bukan hanya dari sisi para perawat atau tenaga medis lainnya, tapi juga dari para pemangku kebijakan/manajemen rumah sakit. Walaupun saat ini sudah ada kebijakan tentang pelayanan kerohanian yang merupakan bagian dari spiritual care di rumah sakit, nyatanya layanan tersebut tidak berjalan sesuai dengan tujuannya. Jika dengan adanya kebijakan yang telah disepakati bersama saja tidak berjalan, sudah tentu yang tanpa kebijakan juga tidak terlaksana. Padahal menurut Bawono (2011) dalam penelitiannya menyimpulkan bahwa aspek spiritualitas-religiusitas merupakan variabel kedua terkuat yang mempengaruhi keputusan pasien berobat. Hal ini menunjukkan bahwa pelayanan spiritualreligiusitas di rumah sakit dapat meningkatkan daya tarik pasien yang membutuhkan jasa perawatan kesehatan. Sehingga penerapan aspek spiritualreligiusitas yang baik diharapkan suatu unit usaha pelayanan kesehatan ini dapat memenangkan persaingan usaha dan eksis dalam dunia pelayanan kesehatan.

6. Harapan terhadap spiritual care

a. Meningkatkan pelayanan

Informan yang mengharapkan kedepannya pelayanan spiritual care dapat lebih terlaksana dengan baik, SPO bimbingan kerohanian lebih diterapkan dan adanya evaluasi pelaksanaan pelayanan spiritual care. Hal ini tentu sangat baik, karena sejalan dengan Bawono (2011) dalam penelitiannya menyimpulkan bahwa aspek spiritualitas-religiusitas merupakan variabel kedua terkuat yang mempengaruhi keputusan pasien berobat.

\section{b. Fasilitas dilengkapi}

Sebagian informan dalam penelitian ini mengungkapkan harapannya yaitu fasilitas yang menunjang kegiatan praktek spiritual care dilengkapi dan adanya formulir (diagnosa spiritual care) pendukung untuk asuhan keperawatannya.

Pendapat ini sesuai dengan penelitian Hodge (2011) pasien mempunyai keinginan untuk terlibat dalam kegiatan ibadah secara rutin. Dengan kegiatan ibadah pasien berharap dapat meningkatkan hubungan dengan Tuhan sehingga dapat mengatasi segala cobaan yang mereka hadapi. Kegiatan yang dilakukan oleh pasien adalah berdo'a, membaca kitab suci, pelayanan keagamaan, mendengar musik rohani dan membaca buku yang bertema rohani.

http://jurnalilmiah.stikescitradelima.ac.id/index.php/JI Vol.3,No.2, Januari 2020 
c. Meningkatkan kualitas SDM

Beberapa informan mengemukakan bahwa harapan terhadap rumah sakit adalah diadakannya pelatihan dalam memberikan spiritual care kepada pasien. Hal ini memang penting, karena menurut penelitian Chan (2010) mengatakan ada korelasi positif antara persepsi spiritual care dan praktik spiritual care diantara perawat, yang berarti bahwa semakin besar persepsi spiritual care perawat, maka spiritual care akan lebih sering disertakan dalam praktik perawat itu. Korelasi ini sangat penting dan bermakna karena dapat mendorong rumah sakit untuk meningkatkan kesadaran perawat tentang spiritual care untuk meningkatkan kualitas praktik spiritual care mereka.

Peneliti sepakat dengan harapan para informan terkait usaha agar pelayanan spiritual care dapat berjalan dengan maksimal. Tetapi menurut peneliti dari ketiga harapan tersebut, yang terpenting saat ini dilakukan adalah peningkatan ilmu pengetahuan tentang spiritual care. Saat pengetahuan para perawat tentang spiritual care meningkat disertai dengan adanya kebijakan yang mewajibkan pelaksanaannya serta adanya evaluasi berkelanjutan, maka peneliti optimis kepuasan pasien khususnya terhadap layanan spiritual di rumah sakit akan meningkat.

\section{SIMPULAN}

Berdasarkan hasil penelitian yang telah dilakukan, ditemukan 5 tema persepsi perawat tentang spiritual care di ruang ICU rumah sakit Medika Stannia Sungailiat, yaitu :

Pemahaman perawat terhadap spiritual care. Pada tema ini perawat memahami spiritual care sebagai perawatan yang berkaitan dengan pemberian bimbingan rohani, perawatan yang berhubungan dengan keagamaan, dan perawatan yang berhubungan dengan kepercayaan.

Cara mengidentifikasi kebutuhan spiritual care psien. Sub tema meliputi dengan menanyakan agama/kepercayaan dan menanyakan pola ibadah pasien.

Pelaksanaan spiritual care oleh perawat. Sub tema meliputi: Pelaksanaan spiritual care oleh perawat tidak terdokumentasi, perawat fokus pada perawatan fisik, dan spiritual care jarang dilakukan.
Hambatan dalam pelaksanaan spiritual care. Hambatan yang dirasakan oleh perawat antara lain kesulitan mengkaji pasien dengan penurunan kesadaran, ambiqu/beda agama atau kepercayaan, dan kurangnya fasilitas.

Harapan perawat terhadap spiritual care, yaitu dengan meningkatkan pelayanan, fasilitas dilengkapi, dan meningkatkan kualitas SDM.

\section{DAFTAR PUSTAKA}

Arini, Hana Nur., Wastu Adi Mulyono,. \& Ida Susilowati. (2015). Hubungan Spiritualitas Perawat dan Kompetensi Asuhan Spiritual. Jurnal Jurusan Keperawatan Fakultas Ilmu Kesehatan Universitas Jenderal Soedirman, 10 (2), 130-140.

Ariyani, Hana., Suryani., \& Aan Nuraeni. (2014). Persepsi Perawat dan Pasien Sindroma Koroner Akut Terhadap Kebutuhan Spiritual. Jurnal Kesehatan Komunitas Indonesia,10 (1), 951961.

Bawono, Anton. (2011). Penerapan Aspek Spiritualitas Religiusitas dalam Keputusan Berobat di Rumah Sakit Islam. Jurnal Penelitian Sosial Keagamaan, 5 (1), 19-39.

Budiono \& Sumirah Budi Pertami. (2015). Konsep Dasar Keperawatan. Jakarta : Bumi Medika.

Chan, M. F. (2010). Factors affecting nursing staff in practicing spititual care. Journal of Clinical Nursing, 19, 2128-2136.

Cooper, Katherine L. (2013). The Impact of Spiritual Care Education Upon Preparing Undergraduate Nursing Students to Provide Spiritual Care. Journal Nurse Education Today. Diakses 20 Maret 2018, dari http://nurseeducationtoday.com/ article/S02606917(12)00110- 4/fulltext.

Hamid, A. Y. (2008). Bunga Rampai: Asuhan Keperawatan Kesehatan Jiwa. EGC : Jakarta.

Hidayat, A. Aziz Alimul \& Musrifatul Uliyah. (2014). Pengantar Kebutuhan Dasar Manusia. Salemba Medika : Jakarta.

http://jurnalilmiah.stikescitradelima.ac.id/index.php/JI Vol.3,No.2, Januari 2020 
Hodge, David R.(2011). Spiritual Needs in Health Care Settings : A Qualitative Meta-Synthesis of Clients Perspectives. Social Work, Vol 56(4), 306-316

Diakses 20 Maret 2018, dari https://academic.oup.com/sw/art icleabstract/56/4/306/1871337?redir ectedfrom=fulltext.

Mahmoodishan, G., Alhani, F., Ahmadi, F.,\& Kazemnejd, A. (2010). Iranian nurses's perceptions of spiritual and spiritual care: A qualitative content analysis study. Journal of Medical Ethics and History of Medicine, 3, 8895.

Ozbasaran, F., Ergul, S., Temel, A., Aslan, G., \& Coban, A. (2011). Turkish nurse's percepstions of spirituality and spiritual care. Journal of clinical Nursing. Diakses 15 Maret 2018, dari https://www.ncbi.nlm.nih.gov/p ubmed/21797943.

Potter, P. A., \& Perry, A. G. (2010). Fundamentals of nursing: Fundamental keperawatan (edisi7) (Adriana Ferderika Nggie \& Marina Albar). Jakarta: Salemba Medika.

Sari, Maya Permata., \& Muhammad Muin. (2009). Persepsi Perawat tentang Kebutuhan Spiritual di Unit Pelaksana Teknis (UPTD) Rumah Sakit Daerah Surakarta. Jurnal Keperawatan, 3 (1), 19-29.

Sianturi, Nurjulianti. (2016). Persepsi Perawat dan Manajer Perawat tentang Spiritual Care di RSUD DR. Djoelham Binjai. Jurnal Kesehatan Bukit Barisan, 1 (1), 55-69.

Siswanto., Susila., \& Suyanto. (2017). Metodologi Penelitian Kombinasi Kualitatif Kuantitatif Kedokteran \& Kesehatan. Boss Script : Klaten Selatan.

Vaughans, Bennita W. (2013). Keperawatan Dasar (Th. Arie Prabawati). Rapha Publishing : Yogyakarta.

Wong, K. F., Lee, L. Y., \& Lee, J. K. (2008). Hongkong enrolled nurses perceptions of spirituality and spiritual care. International Nursing Review.
Diakses 15 Maret 2018, dari https://www.ncbi.nlm.nih.gov/pubmed/195229 $\underline{51}$.

Yusuf, Ah,. Hanik Endang Nihayati., Miranti Florencia., \& Fanni Okviansanti., et al. (2017). Kebutuhan Spiritual : Konsep dan Aplikasi dalam Asuhan Keperawatan. Jakarta: Mitra Wacana Medika.

Zehtab, Samira., Adib-Hajbaghery, Mohsen. (2014). The Importance of Spiritual Care in Nursing. Diakses 26 Maret 2018, dari http://www.ncbi.nlm.nih.gov/pm c/articles/PMC4332997/ 